\title{
REVIEW OF HOUSEHOLD DEBT AND FINANCIAL STABILITY RELATIONSHIP CONCEPT
}

\author{
Tomas Mendelsonas, $M A$ \\ Mykolas Romeris University, Lithuania
}

Doi: 10.19044/elp.v1no1a4 URL:http://dx.doi.org/10.19044/elp.v1no1a4

\begin{abstract}
Concept of relationship between household debt and financial stability is reviewed in this article. First, financial stability concept is briefly introduced. Then relationship between indebtedness level and financial stability is discussed in general. And finally it is concentrated on describing how debt level of household sector is related with financial stability. Household debt has substantial impact on country's financial stability. Excessive borrowing may cause serious systemic problems.
\end{abstract}

Keywords: Financial stability, household debt, systemic risk

\section{Introduction}

Each recession draws additional attention towards analysis of its prevention, causes and rapid recovery. During recent years (before and during the last economic crisis) financial stability was becoming increasingly important question among researchers. Since 1996 until 2005 the number of banks which prepare reviews of financial stability increased from 1 to 40 among members of IMF. Historically microeconomic point of view towards financial stability was dominating, but recently researchers agreed that macroeconomic or systemic approach is required. One of the most important sources of systemic risk is debt or in other words indebtedness of various economic sectors (public sector, enterprises, and households).

In this article it is intended to define household debt and financial stability relationship concept by over viewing recent researches. First, concept of financial stability is briefly described. Then relationship of general indebtedness and financial stability is characterized. And finally it is concentrated on relationship between household debt and financial stability. 


\section{Concept of financial stability}

Two main approaches toward financial stability exist, these are microeconomic and macroeconomic. The main differences are stated below (see Table 1).

Table 1. Macro-versus micro perspective.

\begin{tabular}{|c|c|c|}
\hline & Macroprudential & Microprudential \\
\hline Immediate objective & $\begin{array}{l}\text { To limit instability at system } \\
\text { level }\end{array}$ & $\begin{array}{l}\text { To limit problems at } \\
\text { institutions' level }\end{array}$ \\
\hline Ultimate objective & $\begin{array}{l}\text { To avoid macroeconomic } \\
\text { costs } \\
\text { associated with financial } \\
\text { instability }\end{array}$ & $\begin{array}{l}\text { Consumer protection } \\
\text { (investor/depositor ) }\end{array}$ \\
\hline Risk characterization & $\begin{array}{l}\text { Endogenous (dependent on } \\
\text { collective behavior) }\end{array}$ & $\begin{array}{l}\text { Exogenous (independent from } \\
\text { the } \\
\text { behavior of individual agents) }\end{array}$ \\
\hline $\begin{array}{l}\text { Correlation and common } \\
\text { exposures across } \\
\text { institutions }\end{array}$ & Important & Irrelevant \\
\hline $\begin{array}{l}\text { Calibration of prudential } \\
\text { filters }\end{array}$ & Targets risks at system level & $\begin{array}{l}\text { Targets risks at institutions' } \\
\text { level }\end{array}$ \\
\hline
\end{tabular}

Source: Borio (2003)

Historically microeconomic approach toward financial stability dominated. But currently most attention attracts macroeconomic approach which is relatively much less researched, but is indispensible in order to avoid economic instabilities which could be noticed during last economic crisis.

By utilizing macroeconomic approach financial stability is analyzed from systemic perspective and on macro level. Problems in individual institutions or financial markets does not create threats for financial stability until it is not expected that these problems damages economy as a whole or triggers spreading of problems across whole financial system. Such troubles of separate institutions can even be positive fact from macroeconomic financial stability perspective (Maliszewski, 2009).

Some authors state that in a broad sense general purpose of macroeconomic policy is to reserve financial stability. As specific goals it is possible to underline aim to decrease systemic risks and losses causes by financial crisis (Chiriacescu, 2013).

\section{Debt and financial stability}

Indebtedness level is one of the most important factor which influences financial stability. During last two decades debts increased substantially in OECD countries (Sutherland, D. et al., 2012). High 
indebtedness level transfers economic shocks. Moreover it prevents enterprises and households from reaching optimal consumption and investments, governments cannot properly manage economic downturns.

Weak balance sheet can even prohibit from coping with minor economic fluctuations, which can considerably decreases cash flow towards consumption and investments. Moreover changes of liquidity constrains can increase negative impacts of disorder and influence supply of credit (Barrell et al., 2006).

Pro-cyclic government's borrowing policy dominates. Debt level usually increases during economic downturn which substantially limits actions of a government and triggers threats to financial stability (Egert, 2010; Corsetti et al., 2011).

During last few years OECD intensively researched relationship between debt and macroeconomic stability. In their researches OECD Economic department split analyzed debt into government's debt, enterprises' debt and household debt (Sutherland, D. et al., 2012). Further on in this paper it is concentrated on relationship between household debt and financial stability.

\section{Household debt and financial stability}

Sutherland and Hoeller (2012) describe impacts of different forms of debt to macroeconomic stability. Borrowing by households was increasing rapidly during recent years. The main reasons of debt increase are liberalization of financial markets and financial innovations which created more opportunities for investments. Due to changes in the market credits became available for individuals with low income and number of restrictions applied for borrowing for the first home decreased (Girouard et al., 2006). Macroeconomic environment and other factors also influence increase of borrowing, for example, current and forecasted interest rate, expectations and demographic changes. In the light of liberalization of financial system individuals became more sensible to the changes of asset values (Barrell and Davis, 2007). Increase of real estate prices let the people to increase their debts (Dynan and Kohn, 2007), therefore loan and asset value ratio increased in majority of countries. Decreasing regulations in accommodation financing market and financial innovations are related to housing crediting bubble (Campbell and Hercowitz, 2005).

After review of academic papers it can be stated that analysis of relationship between household debt and financial stability is in relatively early stage. Sutherland, D. et al., (2012) state that increase of household debt indicates upcoming economic and financial system troubles. Moreover relationship between debt level and changes of asset value is present. 
Therefore relationship between household debt and financial stability clearly exists, but it is not sufficiently researched.

During last economic crisis it could be clearly noticed that economic sector of households had crucial impact for development and burst of real estate bubble in USA and in that way triggering of financial instability (Acharya et al., 2009). Debelle (2004) underlined that distribution of the debt has to be analyzed in order to understand the impact of debt to economy. Aggregated debt data does not supply enough information about risk for financial stability arising from changes of indebtedness level. During research of the influence of household debt to financial stability Austria's central bank at the same time analyzes indebtedness level and asset value, in that way defining impact of debt to financial stability (Albacete and Lindner, 2013). International monetary fund (2012) analyzed how financial sector of households influence Spain's financial stability. It was analyzed what part of household debt can be written off (loss in case of default) and if that sum can affect financial stability.

Another research was carried out in Austria in order to find out what influence household debt has on financial stability (Beer and Schurz, 2007). During the research it was concluded that indebtedness level is not a big threat for Austria's financial stability. Debt level is low comparing to other counties and credits are concentrated among wealthy and high income individuals. Another factor diminishing negative influence of debt level is that relatively big proportion of debt are housing credits which are usually backed by pledge of assets. One risk factor exists, big part of credits are taken in foreign currency which exposes households to foreign exchange risk. The riskiest individuals are these who take loans for consumption and have smaller income and fewer assets.

Important lesson which could be learned from recent financial crisis is that economic and financial system stability depends not only on consumption prices and wage inflation. Other important factors are asset price inflation, enterprise and household indebtedness level. Central banks paid too little attention towards these issues and concentrated on historically set goals, therefore they could not manage financial turbulences (Hui, 2011). Hui (2011) analyzes household indebtedness level in Malaysia. For the research he proposes such variables: debt and GDP ratio, debt and income ratio, debt-service ratio, debt and real estate prices ratio. During year 1997 crisis in Asia banks suffered heavy losses due to corporate bankruptcies which was the reason for decrease of corporate financing, but this lead to increase of household financing. Since 2000 to 2010 credits to individuals increased from $34 \%$ to $56 \%$ and therefore exceeded corporate financing.

OECD (2010) in its report about Hungary's financial system's stability states that high household sectors indebtedness in foreign currency 
is a serious problem. When local currency lost its value, citizens faced problem in servicing their liabilities. Moreover prior crisis the financial liabilities were taken not according to abilities to service them. Excessive risk taking and governments' disability to control thoughtless borrowing led to serious problems for financial stability.

In Estonia household debts also grew before the last crisis. This was lead mainly by low interest rates and minor constrains applied by banks. Moreover increasing incomes encourage individuals to borrow. Kask (2003) analyses the impact of household debt to Estonia's financial stability. On macroeconomic level household insolvency risk which influences stability of banks does not varies only because of aggregated debt or income, but also because of other assets in borrower's balance sheet and macroeconomic factors (interest rate and phase of economic cycle). Analysis on macroeconomic level is also burdened by the fact that household sector is not homogenous; it consists of various groups with different income, wealth and age.

If debt level increases because of demographic reasons, growth of income and wealth or economic cycle, then insolvency risk is low and withdrawal of additional credits cannot be treated as excessive. But if banks mitigate crediting constrains, then individuals can exceed optimal indebtedness level during particular economic cycle. The risk for the individual increases then increase of the loan is not tuned to increase of asset value. In such situation paid interests and capital gearing increase, therefore borrower becomes more sensitive towards changes of interest rate and income. Insolvency risk for the creditor depends on ratio of unsecured loans in the whole household portfolio.

If debt servicing problems for households occur on the large scale, then increasing losses due to bad loans weakens solvency of financial intermediaries. In such case banks can restrict crediting or in worst case scenario systemic crisis can be triggered. Negative influence of insolvency depends on ability of individuals to assess undertaken potential risks and intensity of crediting policy.

Increasing burden of loans amplifies sensitivity of household consumption for changes of economic environment. Decreasing consumption is one of the most significant factors negatively impacting financial stability.

Increasing indebtedness level may decrease influence of household sector to economic upturn, because consumption of household sector determines scale and duration of the crisis. High debt level also decreases ability to boost economy through monetary policy (lower interest rate).

Financial stability of household sector makes direct (credit repayment) and indirect (changes of consumption level) impact on banks' and whole economy's financial stability. 
Kaufman (1986) in his research carried out almost thirty years ago tries to attract attention toward increasing indebtedness of USA. The author elaborate that debt increases in all sectors of the economy: household, corporate and government. Household debt and income ratio decreased by $25 \%$, household debt and asset value ratio decreased by $15 \%$ during ten years period. Increasing debt diminishes flexibility of households during changes of economic cycle. The author recommends undertaking proper fiscal and monetary policy in order to keep optimal indebtedness level. Among the list of researcher's recommendations one of the most important is to proceed to systemic risk consideration. In other words monitor and manage financial stability on macroeconomic level. This outlook is currently rapidly developing.

Houben et al. (2004) describes main sources of risks for keeping financial stability. If it is wanted to assess main risks, then it is needed to systemically analyze different parts of financial system (financial market, institutions and infrastructure) and real economy (households, enterprises and government). During analysis it is important to take a look at cross sector and cross country relationships, because the disorders start due to problems in different parts of economy. Interconnection of economy members is very important, so problems in household sector may spread across whole economy and threaten system's financial stability.

Research by Crockett (1996) again backs the same arguments; it is stated that financial situation of enterprises and households is potential source of systemic problems. This goes along with "debt-deflation" outlook developed in 1930s (Fisher, 1993; King, 1994). Number of authors stated that excessive borrowing of individuals during economic boom can trigger recession during economic downturn (Kaufman, 1986; Friedman, 1991). During economic slowdown individuals face debt servicing problems and their net capital decreases, therefore further crediting is restricted which leads to systemic problems.

\section{Conclusion}

Indebtedness level of households can have serious impact on country's financial stability. Household debt is an important source of risk. Due to close interconnection between economy members problems in household sector can cause systemic problems.

Over last two decades household debts were constantly increasing, thus putting more pressure on financial stability. Negative influence of increased debt can be minimal if the debt is in line with larger income, asset price, economic cycle or demographic changes. One more factor which decreases risk is the substantial part of credits withdrawn for accommodation 
financing. On the other hand factor which increases risk is large part of credits issued in foreign currency.

Excessive and not properly controlled borrowing can lead to serious financial stability problems. Individuals can become more sensitive to interest rate and income changes. They can lose flexibility during change of economic cycle. Exceeding optimal debt level during economic upturn may cause serious problems after the economy starts to slow down. Household debts can have direct impact on financial system when banks suffer losses due to clients' insolvency and indirect effects through decrease in consumption.

\section{References:}

Acharya, V., T. Philippon, M. Richardson and N. Roublni. (2009). The Financial Crisis of 2007-2009: Causes and Remedies. In; Financial Markets, institutions \& Instruments, Volume 18, Issue2. May. 89-137.

Albacete, N., and Lindner, P. (2013). Household Vulnerability in Austria -A Microeconomic Analysis Based on the Household Finance and Consumption Survey. Financial Stability Report (Oesterreichische Nationalbank), (25), 57-73.

Barrell, R., E. Davis and O. Pomerantz (2006), "Costs of Financial Instability, Household-sector Balance Sheets and Consumption", Journal of Financial Stability, Vol. 2, pp. 194-216.

Beer, C., and Scurz, M. (2007). Characteristics of Household Debt in Austria. Monetary policy and the economy, Q2/07.

Borio, C. (2003). „Towards a macroprudential framework for financial supervision and regulation?" BIS Working Paper, No. 128.

Campbell, J. and Z. Hercowitz (2005), "The Role of Collateralized Household Debt in Macroeconomic Stabilization", NBER Working Paper, No. 11330.

Chiriacescu, B. (2013). Macroprudential policy and financial stability. Theoretical \& Applied Economics, 20(2), 81-88.

Corsetti, G., K. Kuester, A. Meier and G. Müller (2011), "Sovereign Risk and Macroeconomic Stability", Mimeo.

Crockett, A. (1997) Theory And Practice Of Financial Stability. Essay In International Finances, $\mathrm{N}^{\circ} 203$.

Debelle, G. (2004). Household Debt and the Macroeconomy. In: BIS Quarterly Review March.

Dynan, K. and D. Kohn (2007), "The Rise of U.S. Household Indebtedness: Causes and Consequences", FEDS Working Paper, No. 2007-37.

Egert, B. (2010), "Fiscal Policy Reaction to the Cycle in the OECD", OECD Economics Department Working Papers, No. 763, OECD Publishing. 
Fisher, I. (1993) The Debt-Deflation Theory of Great Depressions. Econometrica, 1, pp. 337-357.

Friedman, Benjamin J. (1991) The Risks of Financial Crises. M. Feldstein (ed.), The Risk of Economic Crisis.

Girouard, N., M. Kennedy and C. André (2006), "Has the Rise in Debt Made Households More Vulnerable?", OECD Economics Department Working Papers, No. 534, OECD Publishing.

Houben, A., Kakes, J. and Schinasi, G. (2004) Toward a Framework for Safeguarding Financial Stability. IMF Working paper, June.

Hui, L. (2011). Household debt in Malaysia - Is it sustainable? Penang Economic Monthly, 13(8), 54-58.

IMF. (2012). Spain: Vulnerabilities of Private Sector Balance Sheets and Risks to the Financial Sector Technical Notes. IMF Country Report No. 12/140, June.

Kask, J. (2003) Household debt and financial stability. Kroon and Economy, No 4.

Kaufman, H. (1986) Debt: the threat to economic and financial stability. Economic Review, December.

Kaufman, H. (1986) Debt: The Threat to Economic and Financial Stability. Economic Review.

King, Mervyn A. (1994) Debt Deflation: Theory and Evidence. European Economic Review, 38, pp. 419-445.

Maliszewski, K. (2009). Measuring stability of the polish financial system by means of a synthetic index. 12Th International Conference On Finance \& Banking: Structural \& Regional Impacts Of Financial Crises, 364-384.

OECD, (2010) Enhancing Financial Stability Through Better Regulation. OECD Economic Surveys: Hungary 2010.2 (2010): 85-115.

Sutherland, D. and P. Hoeller (2012), "Debt and Macroeconomic Stability: An Overview of the Literature and Some Empirics", OECD Economics Department Working Papers, No. 1006, OECD Publishing.

Sutherland, D. et al. (2012), "Debt and Macroeconomic Stability", OECD Economics Department Working Papers, No. 1003, OECD Publishing. 